\title{
Light intensity and sowing depth on the emergence and development of weeds
}

\author{
Guilherme Sasso Ferreira Souza ${ }^{\circledR}$, Ricardo Fagundes Marques ${ }^{\mathrm{b} *} \oplus$, Maria Renata Rocha Pereira ${ }^{\mathrm{c}} \odot$, Sidnei Roberto de Marchi ${ }^{\mathrm{d}} \odot$, \\ Dagoberto Martins ${ }^{\mathrm{b}}$ () \\ a Faculdade de Ciências Agronômicas, Universidade Estadual Paulista "Júlio de Mesquita Filho", Botucatu, SP, Brazil. ' Faculdade de Ciências \\ Agrárias e Veterinárias, Universidade Estadual Paulista "Júlio de Mesquita Filho", Jaboticabal, SP, Brazil. ' Faculdade de Tecnologia de Capão Bonito, \\ Capão Bonito, SP, Brazil. `Universidade Federal de Mato Grosso, Barra do Garças, MT, Brazil.
}

Abstract: Background: Weeds are one of the ecological factors that affect the agricultural economy permanently. Thus, understanding the weed emergence and development is essential in decision making for management strategies.

Objective: This study aimed to evaluate the effect of different sowing depths and light intensities on the emergence and development of the weed species Euphorbia heterophylla and Desmodium tortuosum under field conditions.

Methods: Each species consisted of an experiment carried out in a completely randomized design with four replications. Treatments were arranged in a $6 \times 4$ factorial scheme, with six sowing depths $(0.5,1.0$, 2.0, 4.0, 8.0, and $12.0 \mathrm{~cm})$ associated with four light intensities $(100,70$, 50 , and $30 \%$ of the solar light intensity) obtained with shading screens.
Seedling emergence capacity was evaluated daily to obtain the percentage of emergence and the emergence rate index (ERI). Plant height, time to floral induction, plant dry matter during flowering were also evaluated.

Results: Seedlings of E. heterophylla emerged under all solar radiation conditions and sowing up to $12.0 \mathrm{~cm}$ deep, while seedlings of $D$. tortuosum showed no emergence only at $12.0 \mathrm{~cm}$ deep with light intensities below $70 \%$. The $100 \%$ solar radiation condition provided higher total and daily dry matter accumulation in E. heterophylla plants, while D. tortuosum plants showed higher values for both variables under 70 and $50 \%$ incidence of solar radiation. Conclusions: The full sunlight condition provided the best development of E. heterophylla plants. Different levels of lightness and sowing depths interfere the emergence and the development of $D$. tortuosum plants.

Keywords: Euphorbia heterophylla; Desmodium tortuosum; shading; lightness; field condition

Journal Information:

ISSN - 2675-9462

Website: http://awsjournal.org

Journal of the Brazilian Weed Science Society

How to cite: Souza GSF, Marques RF, Pereira MRR, Marchi SR, Martins D. Light intensity and sowing depth on the emergence and development of weeds. Adv Weed Sci. 2021;39:02100043. https://doi.org/10.51694/AdvWeedSci/2021;39:00016

Approved by:

Editor in Chief: Anderson Luis Nunes

Associate Editor: Daniel Valadão Silva

Conflict of Interest: The authors declare no conflict of interest regarding the publication of this manuscript.

Received: October $2^{\text {nd }}, 2020$

Approved: September 23, 2021

* Corresponding author: <rfmarques94@gmail.com >

\section{(c) (4)}

This is an open-access article distributed under the terms of the

Creative Commons Attribution License, which permits unrestricted use, distribution, and reproduction in any medium, provided that the original author and source are credited.

Copyright: 2021

\section{Introduction}

Weeds are one of the ecological factors that most affect the agricultural economy permanently because their presence in cultivated areas causes losses to crops and their control entails expenses that increase production costs (Monquero et al., 2015; Marchi et al., 2019). One of the highest limitations for implementing a weed management program is the lack of knowledge on the biology and ecology of the main species (Ramesh et al., 2017). Thus, some studies have been developed aiming at a better understanding of the growth and development of these plants for their effective management (Marchi et al., 2020).

In general, seed germination is regulated by the interaction between environmental conditions and the state of physiological aptitude, and each species of plant requires a set of environmental resources necessary for the germination of its seeds, such as water, light, and temperature availability and sowing depth (Zuffo et al., 2014). Thus, knowledge of the emergence capacity of seedlings from seeds located at different soil depths can assist in the weed management through the adoption of methods that reduce or prevent their occurrence (Monquero et al., 2015; Montanha et al., 2018; Marques et al., 2019). An example is the mechanical control using equipment for soil preparation capable of providing seed incorporation at depths unfavorable to that ideal for seedling emergence (Maciel, 2014). In addition, weed seedlings may be shaded due to a slight delay in the emergence and show slower initial growth (Monquero et al., 2012).

Similarly to the depth at which seeds are in the soil profile affects their germination and emergence and development of plants, light is also required for the germination of a large number of weed species (Lessa et al., 2013). Light controls the beginning of the germination of photosensitive seeds and phytochromes are responsible for the perception and transduction of the light signal. This chromoprotein has two basic forms: an inactive form, which is activated by absorbing red light, inducing the production of $\mathrm{Ga}_{3}$ and triggering the beginning of germination, and an active form, which is inactivated when illuminated with far-red light, with consequent production abscisic acid (ABA), inducing seeds to a state of dormancy (Silva et al., 2019). In addition to this, the perception of light quality occurs through phytochrome. The mode 
of action of these pigments depends on the type of incident radiation, as light with a high red/extreme red (V/VE) ratio induces the active form (FVe), promoting the germination of photosensitive seeds, while under light with a low V/VE ratio, the phytochrome becomes inactive (FV), inhibiting germination (Vieira et al., 2018).

Thus, understanding the mode of propagation, dispersion, emergence and development of species to be controlled is important because attempts to control them may result in uncoordinated, costly, and ineffective activities without observing these characteristics (Marques et al., 2019). In this sense, this study aimed to evaluate the effect of different sowing depths and light intensities on the emergence and development of the weed species Euphorbia heterophylla L. and Desmodium tortuosum (Sw.) DC. under field conditions.

\section{Material and Methods}

The study was set up and carried out under field conditions in an area belonging to the School of Agriculture (Universidade Estadual Paulista - Unesp), campus of Botucatu, SP, Brazil, with geographic coordinates of $22^{\circ} 07^{\prime} 56^{\prime \prime} \mathrm{S}$ and $74^{\circ} 66^{\prime} 84^{\prime \prime}$ WGr. and altitude of $762 \mathrm{~m}$. The soil in the experimental area is clay-textured litholic Neosol (Sérgio et al., 2005), with the physical and chemical characteristics shown in Table 1.

Each weed species (D. tortuosum and E. heterophylla) constituted an experiment conducted in a completely randomized design, with four replications. The treatments were arranged in a $6 \times 4$ factorial scheme, with the first factor consisting of six sowing depths $(0.5,1.0,2.0,4.0$, 8.0 , and $12.0 \mathrm{~cm}$ ) and the second factor consisting of four light intensities $(100,70,50$, and $30 \%$ of the solar light intensity) obtained through the use of specific agricultural shading screens.

The mean data on the amount of light and soil temperature measured in each treatment in the morning and afternoon in the experimental area are shown in Table 2. The photosynthetically active radiation (PAR) was measured as the photosynthetically active photon flux density (PPFD) $\left(\mathrm{mmol} \mathrm{s}^{-1} \mathrm{~m}^{-2}\right)$ at ground level using a quantum sensor (LI190, LI-COR, USA) coupled to a porometer (LI-1600 LICOR Steady State Porometer, LI-COR, USA).

The experimental plots consisted of $1.0 \mathrm{~m}$ wide, and $2.0 \mathrm{~m}$ long seedbeds mechanical raised with a rotary hoe. Within these seedbeds, four replications were sown with 25 viable seeds of each species per row for each treatment, at a $25 \mathrm{~cm}$ spacing from one row to another. Sowing was always done following the same pattern of depth arrangement, from the smallest to the largest, to better visualize and evaluate the plants in the field.

Sowing was performed manually, and the studied depths were obtained using a wooden structure for drilling the sowing row, which was built with the exact size of each depth to maintain the uniformity of the sowing depth across the furrow (Figure 1). The main seedbeds were prepared in the north-south direction with the sowing furrows in the east-west direction to avoid possible undesirable shading.

The different light intensities were obtained using agricultural screens manufactured with black polyethylene $\left(\right.$ Sombrite $\left.^{*}\right)$, which allow the passage of 70,50 , and $30 \%$

\begin{tabular}{|c|c|c|c|c|c|c|c|c|c|}
\hline $\begin{array}{l}\mathrm{pH} \\
\mathrm{CaCl}_{2}\end{array}$ & O.M. ${ }^{11}$ & $P_{\text {-resin }}$ & K & $\mathrm{Ca}$ & Mg & $\mathrm{H}+\mathrm{Al}$ & s & $\mathrm{CEC}^{\prime 2}$ & $V^{\prime 3}$ \\
\hline $\begin{array}{l}(0,01 \\
\left.\mathrm{mol} \mathrm{L}^{-1}\right)\end{array}$ & $\stackrel{9}{\mathrm{dm}^{-3}}$ & $\begin{array}{c}\mathrm{mg} \\
\mathrm{dm}^{-3}\end{array}$ & \multicolumn{5}{|c|}{------- $\mathrm{mmol}_{\mathrm{c}} \mathrm{dm}^{-3}$-------- } & & $\%$ \\
\hline 4.8 & 22 & 11 & 1.6 & 33 & 14 & 46 & 48 & 94 & 51 \\
\hline \multicolumn{10}{|c|}{ Granulometry $(\mathrm{g} \mathrm{kg-1})$} \\
\hline Clay & \multicolumn{2}{|c|}{ Silt } & \multicolumn{2}{|c|}{ Coarse Sand } & \multicolumn{3}{|c|}{ Thin Sand } & \multicolumn{2}{|c|}{ Total Sand } \\
\hline 449 & \multicolumn{2}{|c|}{163} & \multicolumn{2}{|c|}{100} & \multicolumn{3}{|c|}{288} & \multicolumn{2}{|c|}{388} \\
\hline
\end{tabular}

\begin{tabular}{|c|c|c|c|c|c|c|c|c|}
\hline \multirow[b]{2}{*}{ Hour } & \multirow{2}{*}{$\begin{array}{c}\text { Solar } \\
\text { intensity }\end{array}$} & \multirow{2}{*}{$\begin{array}{l}\text { Light } \\
\left(\mathrm{mmol} \mathrm{s}^{-1} \mathrm{~m}^{-2}\right)\end{array}$} & \multicolumn{6}{|c|}{ Soil Temperature $\left({ }^{\circ} \mathrm{C}\right)$} \\
\hline & & & $\begin{array}{l}0.5 \\
\mathrm{~cm}\end{array}$ & $\begin{array}{l}1.0 \\
\mathrm{~cm}\end{array}$ & $\begin{array}{l}2.0 \\
\mathrm{~cm}\end{array}$ & $\begin{array}{l}4.0 \\
\mathrm{~cm}\end{array}$ & $\begin{array}{l}8.0 \\
\mathrm{~cm}\end{array}$ & $\begin{array}{l}12.0 \\
\mathrm{~cm}\end{array}$ \\
\hline 09:30 & $100 \%$ & 1830 & 34 & 34 & 34 & 33 & 29 & 26 \\
\hline 09:30 & $70 \%$ & 840 & 31 & 31 & 31 & 30 & 26 & 25 \\
\hline 09:30 & $50 \%$ & 760 & 30 & 30 & 30 & 28 & 26 & 25 \\
\hline 09:30 & $30 \%$ & 660 & 30 & 30 & 30 & 29 & 26 & 25 \\
\hline $15: 30$ & $100 \%$ & 1920 & 42 & 42 & 42 & 40 & 36 & 33 \\
\hline $15: 30$ & $70 \%$ & 920 & 34 & 33 & 32 & 31 & 30 & 28 \\
\hline $15: 30$ & $50 \%$ & 840 & 33 & 33 & 32 & 31 & 30 & 28 \\
\hline 15:30 & $30 \%$ & 710 & 32 & 31 & 31 & 30 & 29 & 28 \\
\hline
\end{tabular}

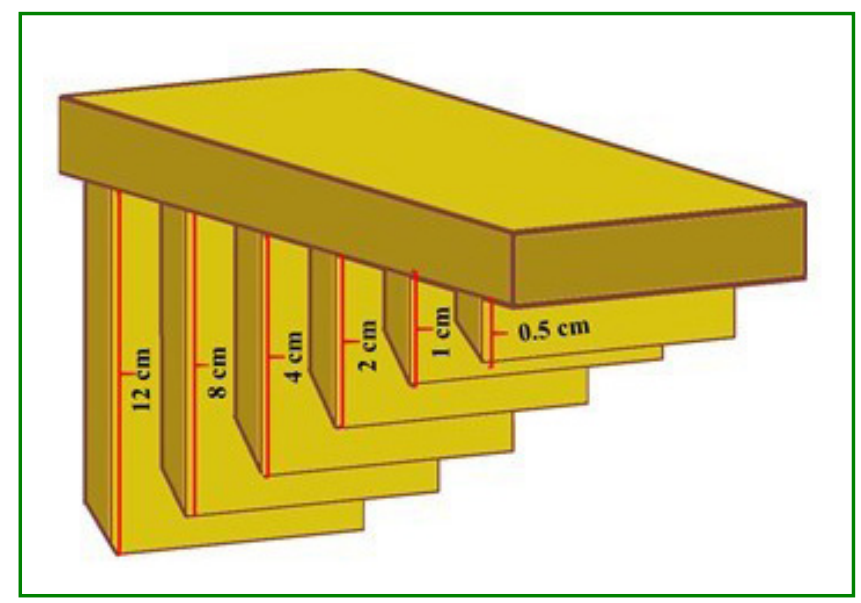

Figure 1 - Scheme of the equipment for drilling the soil at different depths. 
light intensities. These screens were installed on the sowing beds covering the entire surface and sides of beds at a height of $80 \mathrm{~cm}$ to enable evaluations inside the bed and avoid the passage of unwanted light intensity during the evaluations. The structure was assembled with the possibility of bilateral opening, that is, it could be opened from either side, always keeping the top and side covers intact. The choice of the side to be opened depending on the sun position at the time of the evaluations, thus preventing plants from receiving unwanted sunlight at any time during the experimental period. Irrigations with the application of $10 \mathrm{~mm}$ of water were carried out three times a week, totaling $30 \mathrm{~mm}$ per week, using a sprinkler system. The weeding of unwanted plants was carried out whenever necessary.

The emergence of seedlings of the studied species was monitored for a minimum period of 26 days from sowing by counting and removing the emerged plants to obtain the percentage of emergence and calculate the emergence rate index (ERI). This index was calculated using the equation proposed by Maguire (1962), as follows: ERI $=$ G1/N1 $+\mathrm{G} 2 / \mathrm{N} 2+\ldots+\mathrm{Gn} / \mathrm{Nn}$, where ERI is the emergence rate index, G1...n is the number of normal seedlings emerged computed in the counts, and N1...n is the number of days from sowing to the first, second, and $\mathrm{n}$-th evaluation. The counts in each experimental plot were performed daily from the day the first plant emerged.

The first three plants that emerged from each depth were evaluated in all plots that showed emergence regarding the height (measured with a graduated ruler) and time until the floral induction of the species, in addition to the measuring of the total and daily dry matter accumulation of plants at flowering, being that two plants were used to measure the daily accumulation of dry matter and one was used to measure the total accumulation of dry matter at the end of the experiment. For this purpose, the samples with each plant were placed in paper bags and kept in an oven with forced air circulation at $65^{\circ} \mathrm{C}$ until reached a constant weight, when they were then weighed on a $0.01 \mathrm{~g}$ precision scale.

The observed values were subjected to the normality test by the Shapiro-Wilk at $5 \%$ significance and to the analysis of variance by F-Test and the effects of treatments were compared by the Tukey test at $5 \%$ probability.

\section{Results and Discussion}

\subsection{Euphorbia heterophylla}

Plants of the species E. heterophylla emerged under all evaluated light conditions and sowing depths between 0.5 and $12.0 \mathrm{~cm}$. However, only the different sowing depths affected the time in days for seedling emergence (Table 3).

Seeds of E. heterophylla placed at 8.0 or $12.0 \mathrm{~cm}$ in depth resulted in seedlings emerging in a shorter time compared to sowing at depths of 0.5 to $4.0 \mathrm{~cm}$ (Table 3). Therefore, it is observed that, for the most superficial layers of the soil profile, there was a greater need for time for seedling
Table 3. Days for the emergence of Euphorbia heterophyllo seedlings sown at different depths and submitted to different solar radiation intensities.

\begin{tabular}{|c|c|c|}
\hline \multicolumn{3}{|c|}{ SOWING DEPTH (cm) } \\
\hline 0.5 & 7.37 & A \\
\hline 1.0 & 6.81 & A \\
\hline 2.0 & 6.57 & A \\
\hline 4.0 & 6.50 & A \\
\hline 8.0 & 5.12 & C \\
\hline 12.0 & 5.50 & $\mathrm{BC}$ \\
\hline \multicolumn{3}{|c|}{ \% OF SOLAR RADIATION } \\
\hline 100 & \multicolumn{2}{|c|}{6.21} \\
\hline 70 & \multicolumn{2}{|c|}{6.08} \\
\hline 50 & \multicolumn{2}{|c|}{6.42} \\
\hline 30 & \multicolumn{2}{|c|}{6.42} \\
\hline $\mathrm{F}_{\mathrm{LIGHT}}(\mathrm{L})$ & \multicolumn{2}{|c|}{$0.878^{N S}$} \\
\hline $\mathrm{F}_{\mathrm{DEPTH}}(\mathrm{D})$ & \multicolumn{2}{|c|}{$15.068^{* *}$} \\
\hline$F(L) \times(D)$ & \multicolumn{2}{|c|}{$1.486^{\mathrm{NS}}$} \\
\hline LSD (L) & \multicolumn{2}{|c|}{0.65} \\
\hline LSD (D) & \multicolumn{2}{|c|}{0.89} \\
\hline C. V. (\%) & \multicolumn{2}{|c|}{13.7} \\
\hline
\end{tabular}

**Significant at $1 \%$ probability; NS - not significant. Means followed by the same uppercase letter in the column do not differ statistically from each other by the Tukey test $(p<0.05)$.

emergence. It is important to highlight that light is necessary for germination of a large number of weed species (Silva et al., 2019). Thus, some species have seeds that germinate only under rapid exposure to light and others that start this process after a long period of exposure, plus, seeds in which germination is triggered only in the dark and indifferent to light (Guimarães et al., 2018).

Unlike the results obtained regarding the number of days for the emergence of E. heterophylla seedlings (Table 3), the percentage of seedling emergence was not affected by the evaluated factors, that is, E. heterophylla seedlings showed similar percentages of emergence at sowing depths between 0.5 and $12.0 \mathrm{~cm}$ under 30, 50, 70, and $100 \%$ solar radiation conditions. Similar behavior was observed the emergence rate index (ERI) of E. heterophylla seedlings (Table 4).

Some weed species have seeds with little storage material and can germinate only after stimulated by light at low depths. However, other species do not need this stimulus and, therefore, can emerge at higher depths, as their seeds have higher storage of essential compounds for germination and emergence (Montanha et al., 2018). However, plants of E. heterophylla, as well as Euphorbia brasiliensis (Klein, Felippe, 1991), have a positive photoblastism, i.e., they need light to begin the germination and enable their response to daily and annual thermal changes (Marques et al., 2012). This need for light should affect the germinative response of this species when sown at high depths, but this study showed that even at high sowing depths, such as $12.0 \mathrm{~cm}$, where light becomes much reduced, plants of E. heterophylla 
presented percentages of emergence not differing from sowing in superficial layers.

The results complement the data reported by Machado Neto and Pitelli (1988), who observed that the sowing depth showed no effect on the germination and emergence of $E$. heterophylla, except for the superficial depth. In this case, even the superficial sowing, such as the depth of $0.5 \mathrm{~cm}$, showed no differences in the percentage of the emergence of $E$. heterophylla seedlings. These results reinforce the high germination and emergence capacity of this important weed species in a wide range of soil depth.

Similar to the percentage of emergence and ERI evaluations (Table 4), the time from sowing to the flowering of E. heterophylla plants was not affected by the evaluated light conditions, as all plants presented inflorescences at 40 days after sowing (Table 5). These results show that $E$. heterophylla plants completed their cycle in a similar period, regardless of the light condition to which they were submitted ( 100 or even $30 \%$ of the solar radiation). Although

\begin{tabular}{|c|c|c|c|c|}
\hline \multicolumn{5}{|c|}{$\begin{array}{l}\text { Table } 4 \text { - Percentage of emergence and eme } \\
\text { index (ERI) of Euphorbia heterophylla seedlin } \\
\text { different depths and submitted to different sc } \\
\text { intensities. } \\
\text { PERCENTAGE OF EMERGENCE (\%) }\end{array}$} \\
\hline \multirow{2}{*}{ SOWING DEPTH $(\mathrm{cm})$} & \multicolumn{4}{|c|}{ \% OF SOLAR RADIATION } \\
\hline & 100 & 70 & 50 & 30 \\
\hline 0.5 & 46.47 & 39.10 & 34.56 & 33.01 \\
\hline 1.0 & 48.71 & 44.87 & 35.14 & 29.80 \\
\hline 2.0 & 51.60 & 40.06 & 52.99 & 46.47 \\
\hline 4.0 & 44.42 & 53.85 & 59.40 & 48.40 \\
\hline 8.0 & 52.24 & 34.61 & 31.62 & 35.89 \\
\hline 12.0 & 39.74 & 30.12 & 23.51 & 23.71 \\
\hline $\mathrm{F}_{\mathrm{LIGHT}}(\mathrm{L})$ & \multicolumn{4}{|c|}{$0.729^{N S}$} \\
\hline $\mathrm{F}_{\text {DEPTH }}(\mathrm{D})$ & \multicolumn{4}{|c|}{$1.449^{\mathrm{NS}}$} \\
\hline$F(L) \times(D)$ & \multicolumn{4}{|c|}{$1.001^{\mathrm{NS}}$} \\
\hline LSD (L) & \multicolumn{4}{|c|}{32.92} \\
\hline LSD (D) & \multicolumn{4}{|c|}{36.65} \\
\hline C. V. (\%) & \multicolumn{4}{|c|}{44.7} \\
\hline \multicolumn{5}{|c|}{$(E R I)$} \\
\hline \multirow{2}{*}{ SOWING DEPTH $(\mathrm{cm})$} & \multicolumn{4}{|c|}{ \% OF SOLAR RADIATION } \\
\hline & 100 & 70 & 50 & 30 \\
\hline 0.5 & 4.10 & 3.38 & 2.45 & 2.75 \\
\hline 1.0 & 2.83 & 3.88 & 5.19 & 2.37 \\
\hline 2.0 & 4.31 & 4.43 & 4.58 & 3.86 \\
\hline 4.0 & 2.57 & 5.67 & 4.72 & 4.06 \\
\hline 8.0 & 5.01 & 4.27 & 1.73 & 3.13 \\
\hline 12.0 & 4.05 & 3.36 & 1.75 & 2.29 \\
\hline$F_{L I G H T}(L)$ & \multicolumn{4}{|c|}{$2.225^{\mathrm{NS}}$} \\
\hline$F_{\text {DEPTH }}(D)$ & \multicolumn{4}{|c|}{$2.026^{\mathrm{NS}}$} \\
\hline$F(L) \times(D)$ & \multicolumn{4}{|c|}{$2.225^{\mathrm{NS}}$} \\
\hline LSD (L) & \multicolumn{4}{|c|}{3.29} \\
\hline LSD (D) & \multicolumn{4}{|c|}{3.67} \\
\hline C. V. (\%) & \multicolumn{4}{|c|}{49.1} \\
\hline
\end{tabular}

NS - not significant. it was not evaluated in this research, it is worth noting that the flowering of some species of the Euphorbiaceae family may be directly influenced by the photoperiod of the region, as reported in the research of Neves et al. (2010), inferring that the flowering of E. heterophylla plants at 40 days after sowing, in the present study, may have occurred due to photoperiod.

The only factor that affected the height of $E$. heterophylla plants at the time of flowering was the light intensity at which the plants developed, with the largest plants being observed in the treatment with $100 \%$ solar radiation. A reduction in light led to a reduction in plant height during flowering, with similar means under 70 and $50 \%$ solar radiation conditions and even lower under the $30 \%$ solar radiation condition. The difference in the mean height of $E$. heterophylla plants between the treatment with the highest light and that with the lowest light reached 78.84\% (Table 6).

Table 5 - Days for flowering of Euphorbia heterophylla plants sown at different depths and submitted to different solar radiation intensities.

\begin{tabular}{l|l|l|l|l|}
\hline SOWING DEPTH & \multicolumn{4}{c}{ \% OF SOLAR RADIATION } \\
\cline { 2 - 5 } (cm) & $\mathbf{1 0 0}$ & $\mathbf{7 0}$ & $\mathbf{5 0}$ & $\mathbf{3 0}$ \\
\hline 0.5 & 40 & 40 & 40 & 40 \\
\hline 1.0 & 40 & 40 & 40 & 40 \\
\hline 2.0 & 40 & 40 & 40 & 40 \\
\hline 4.0 & 40 & 40 & 40 & 40 \\
\hline 8.0 & 40 & 40 & 40 & 40 \\
\hline 12.0 & 40 & 40 & 40 & 40 \\
\hline
\end{tabular}

Table 6 - Height at flowering (cm) of Euphorbia heterophylla plants sown at different depths and submitted to different solar radiation intensities.

\begin{tabular}{|c|c|}
\hline \multicolumn{2}{|c|}{ SOWING DEPTH $(\mathrm{cm})$} \\
\hline 0.5 & 12.69 \\
\hline 1.0 & 12.84 \\
\hline 2.0 & 13.02 \\
\hline 4.0 & 14.32 \\
\hline 8.0 & 14.02 \\
\hline 12.0 & 13.60 \\
\hline \multicolumn{2}{|c|}{ \% OF SOLAR RADIATION } \\
\hline 100 & 16.99 \\
\hline 70 & 13.31 \\
\hline 50 & 13.87 \\
\hline 30 & 9.50 \\
\hline$F_{\text {LIGHT }}(L)$ & $40.147^{* *}$ \\
\hline $\mathrm{F}_{\mathrm{DEPTH}}$ (D) & $\begin{array}{l}1.261^{\mathrm{NS}} \\
0.412^{\mathrm{NS}}\end{array}$ \\
\hline$F(L) \times(D)$ & \multirow{2}{*}{1.80} \\
\hline LSD (L) & \\
\hline LSD (D) & 2.46 \\
\hline C. V. (\%) & 17.7 \\
\hline
\end{tabular}

** Significant at $1 \%$ probability; NS - not significant. Means followed by the same uppercase letter in the column do not differ statistically from each other by the Tukey test $(p<0.05)$. 
The total and daily dry matter accumulation were influenced only by the light intensity to which the E. heterophylla plants were submitted during its development (Table 7), as observed for plant height (Table 5). The shading, regardless of the percentage of blocked solar radiation, promoted a significant reduction of the total and daily dry matter accumulation per plant of E. heterophylla, corresponding to a reduction of at least $84.21 \%$ and $83.85 \%$, respectively, when compared to the condition of full sunlight (Table 7).

These results showed that sowing depth affected only the time for the emergence of $E$. heterophylla seedlings, while light conditions affected plant height during flowering, dry matter, and daily dry matter accumulation. Moreover, the full sunlight condition provided E. heterophylla plants with better conditions for their development after emergence. Due to this, it is worthy to mentioning that the use of cultural treatments that promote reduction of solar radiation can be effective in controlling weed growth and development (Marchi et al., 2020), like E. heterophylla.

\subsection{Desmodium tortuosum}

Seedlings of $D$. tortuosum emerged five days after sowing when placed in the most superficial soil layers (depths of 0.5 to $4.0 \mathrm{~cm}$ ), regardless of the light intensity to which they were subjected. The time needed for

Table 7 - Total dry matter accumulation at flowering

and daily dry matter accumulation until the flowering of

Euphorbia heterophylla plants sown at different depths and submitted to different solar radiation intensities.

\begin{tabular}{|c|c|c|c|c|}
\hline & \multicolumn{2}{|c|}{$\begin{array}{c}\text { TOTAL DRY } \\
\text { MATTER } \\
\text { ACCUMULATION } \\
\text { (g) }\end{array}$} & \multicolumn{2}{|c|}{$\begin{array}{c}\text { DAILY DRY } \\
\text { MATTER }\end{array}$} \\
\hline \multicolumn{5}{|c|}{ SOWING DEPTH (cm) } \\
\hline 0.5 & \multicolumn{2}{|c|}{0.22} & \multicolumn{2}{|c|}{0.0055} \\
\hline 1.0 & \multicolumn{2}{|l|}{0.22} & \multicolumn{2}{|c|}{0.0056} \\
\hline 2.0 & \multicolumn{2}{|l|}{0.29} & \multicolumn{2}{|c|}{0.0073} \\
\hline 4.0 & \multicolumn{2}{|l|}{0.38} & \multicolumn{2}{|c|}{0.0095} \\
\hline 8.0 & \multicolumn{2}{|l|}{0.36} & \multicolumn{2}{|c|}{0.0090} \\
\hline 12.0 & \multicolumn{2}{|l|}{0.29} & \multicolumn{2}{|c|}{0.0072} \\
\hline \multicolumn{5}{|c|}{ \% OF SOLAR RADIATION } \\
\hline 100 & 0.76 & A & 0,0192 & A \\
\hline 70 & 0.12 & B & 0,0031 & B \\
\hline 50 & 0.13 & B & 0,0034 & B \\
\hline 30 & 0.15 & $\mathrm{~B}$ & 0,0038 & B \\
\hline $\mathrm{F}_{\mathrm{LIGHT}}(\mathrm{L})$ & \multicolumn{2}{|c|}{$96.989^{* *}$} & \multicolumn{2}{|c|}{$96.618^{* *}$} \\
\hline $\mathrm{F}_{\text {DEPTH }}(\mathrm{D})$ & \multicolumn{2}{|c|}{$1.931^{\mathrm{NS}}$} & \multicolumn{2}{|c|}{$1.926^{\mathrm{NS}}$} \\
\hline$F(L) \times(D)$ & \multicolumn{2}{|c|}{$1.668^{\mathrm{NS}}$} & \multicolumn{2}{|c|}{$1.667^{\mathrm{NS}}$} \\
\hline LSD (L) & \multicolumn{2}{|l|}{0.12} & \multicolumn{2}{|c|}{0.0029} \\
\hline LSD (D) & \multicolumn{2}{|l|}{0.16} & \multicolumn{2}{|c|}{0.0040} \\
\hline C. V. (\%) & \multicolumn{2}{|l|}{52.8} & \multicolumn{2}{|c|}{52.9} \\
\hline
\end{tabular}

** Significant at $1 \%$ probability; NS - not significant. Means followed by the same uppercase letter in the column do not differ statistically from each other by the Tukey test $(p<0.05)$. emergence increased in all the evaluated light conditions with an increase in the depth at which the seeds were sown, with shading conditions of 30,50 , and $70 \%$ solar radiation providing no emerged plants at the sowing depth of $12.0 \mathrm{~cm}$ (Table 8).

Seedlings of $D$. tortuosum emerged at sowing depths from 0.5 to $12.0 \mathrm{~cm}$ under the $100 \%$ solar radiation condition, but sowing depths of 8.0 and $12.0 \mathrm{~cm}$ required 5.25 and 11 days more for emergence, respectively, than the depth of up to $4.0 \mathrm{~cm}$. Similar behavior was observed for the 70,50 , and $30 \%$ solar radiation conditions, in which the time for the emergence of $D$. tortuosum seedlings sown at a depth of 8.0 $\mathrm{cm}$ took, on average, $9,8.25$, and 8.5 days more than plants sown at a depth of $4.0 \mathrm{~cm}$ (Table 8 ).

These results show the capacity of $D$. tortuosum plants to emerge from depths up to $12.0 \mathrm{~cm}$, depending on the solar intensity, but these plants emerged much more quickly when arranged at a depth of up to 4.0 cm. Oliveira Jr. and Delistoianov (1996) evaluated Desmodium purpureum (Mill.) Fawc. \& Rendle seeds placed to germinate at different depths and verified that their emergence was not feasible at depths higher than $3.75 \mathrm{~cm}$, indicating that the positioning of seeds below this depth can work as a cultural method of controlling this species, as it could induce the seed dormancy process. Excessive depths increase the mechanical resistance, hindering the germination process and plant growth, besides reducing the temperature and $\mathrm{O}_{2}$ availability, as well as increasing $\mathrm{CO}_{2}$ accumulation, forming fermented compounds during the respiration process (Taiz, Zeiger, 2013) and affecting the germination process (Zuffo et al., 2014).

Sowing at higher depths was the only significant factor for the percentage of emergence. Sowing deeper than 4.0 $\mathrm{cm}$ resulted in significant reductions in the percentage

\begin{tabular}{|c|c|c|c|c|c|c|c|c|}
\hline \multirow{3}{*}{$\begin{array}{l}\begin{array}{l}\text { SOWING } \\
\text { DEPTH }(\mathrm{cm})\end{array} \\
0.5\end{array}$} & \multicolumn{8}{|c|}{ \% OF SOLAR RADIATION } \\
\hline & \multicolumn{2}{|c|}{100} & \multicolumn{2}{|c|}{70} & \multicolumn{2}{|c|}{50} & \multicolumn{2}{|c|}{30} \\
\hline & 5.00 & Сa & 5.00 & Ba & 5.00 & Ba & 5.00 & Ba \\
\hline 1.0 & 5.00 & $\mathrm{Ca}$ & 5.00 & Ba & 5.00 & Ba & 5.00 & Ва \\
\hline 2.0 & 5.00 & $\mathrm{Ca}$ & 5.00 & Ba & 5.00 & Ba & 5.00 & Ba \\
\hline 4.0 & 5.00 & Ca & 5.00 & Ba & 5.00 & Ba & 5.00 & Ba \\
\hline 8.0 & 10.25 & $\mathrm{Bb}$ & 14.50 & Aa & 13.25 & Aab & 13.50 & Aab \\
\hline 12.0 & 16.00 & Aa & - & & - & & - & \\
\hline $\mathrm{F}_{\mathrm{LIGHT}}(\mathrm{L})$ & \multicolumn{8}{|c|}{$6.739^{* *}$} \\
\hline $\mathrm{F}_{\mathrm{DEPTH}}$ (D) & \multicolumn{8}{|c|}{$43.525^{* *}$} \\
\hline $\mathrm{F}(\mathrm{L}) \times(\mathrm{D})$ & \multicolumn{8}{|c|}{$12.089^{* \star}$} \\
\hline LSD (L) & \multicolumn{8}{|c|}{3.58} \\
\hline LSD (D) & \multicolumn{8}{|c|}{3.99} \\
\hline C. V. (\%) & \multicolumn{8}{|c|}{26.3} \\
\hline
\end{tabular}

${ }^{*}$ Significant at $1 \%$ probability. Means followed by the same uppercase letter in the column do not differ statistically from each other by the Tukey test $(p<0.05)$. 
of emergence of $D$. tortuosum seedlings, reaching values of up to $0.24 \%$ of emergence in the sowing at a depth of $12.0 \mathrm{~cm}$ (Table 9).

Thus, it is evident that the percentage of emergence reductions due to the increase in the sowing depth may have occurred due to the decrease in solar radiation or due to other factors. These may be: the non-incidence of solar radiation imposed by the natural soil barrier on seeds that were located at higher depths; or due to the amount of seed reserve material of both species being insufficient to break the physical barrier imposed by the soil (Pacheco et al., 2010; Santos et al., 2015); or by the process of secondary or induced dormancy, which refers to the state of dormancy induction under environmental conditions not favorable to germination, in non-dormant seeds or in those whose primary dormancy has been overcome (Marques et al., 2019); or even because of the thermal amplitude observed at the different sowing depths, as shown in Table 2.

The different light intensities and sowing depths, and the interaction between these two factors has significantly influenced the ERI of D. tortuosum seedlings (Table 10). The ERI was zero in the cases in which plants were sown at a depth of $12.0 \mathrm{~cm}$ in treatments with 70,50 , and $30 \%$ solar radiation, as there was no emergence. The highest ERI of $D$. tortuosum plants was obtained under $100 \%$ solar radiation and sowing depth of $2.0 \mathrm{~cm}$. In situations of light reduction, the ERI of $D$. tortuosum seedlings was similar in sowing depths from 0.5 to $2.0 \mathrm{~cm}$, being reduced with increasing sowing depth. Treatments with sowing at a depth of $2.0 \mathrm{~cm}$

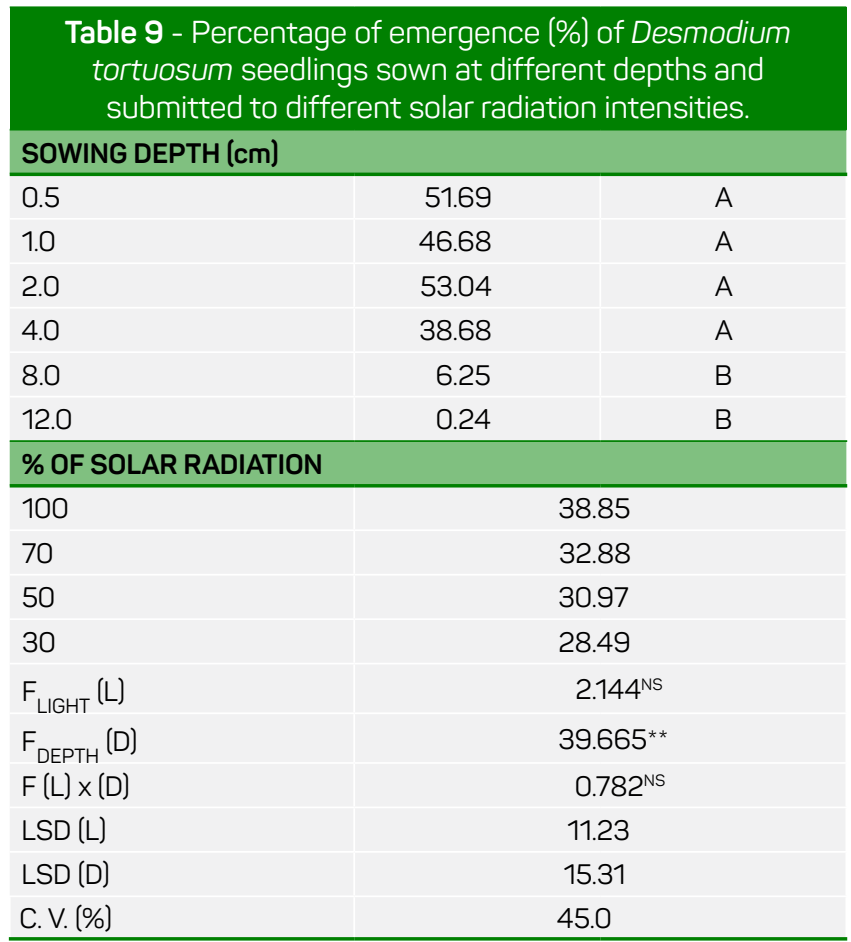

**Significant at $1 \%$ probability; NS - not significant. Means followed by the same uppercase letter in the column do not differ statistically from each other by the Tukey test $(p<0.05)$. showed effects of different light intensities on the ERI of $D$. tortuosum seedlings, which decreased as the light in which the seeds were sown reduced (Table 10).

The different light intensities also affected the time required for the flowering of $D$. tortuosum plants, with the first floral inductions presented by plants developed in full sunlight at 118 days after sowing (Table 10). These results are similar to those observed by Procópio et al. (2003), who reported a period of 137 days for the total cycle of $D$. tortuosum plants under field conditions and full sunlight.

Shading conditions induced an increase in the time for flowering of $D$. tortuosum plants regarding the full sunlight condition. This period was 20 and 21 days longer for plants developed at $30 \%$ and 50 and $70 \%$ shade, respectively (Table 10). These results show that a reduction in light under which the plants were developed reflected directly on the time for flowering, a fact that did not prevent the flowering from happening.

Moreover, both the light intensities and sowing depths and the interaction between these factors were significant at $\mathrm{P}<0.05$ for the variable plant height at the flowering of D. tortuosum (Table 11).

Table 10 - Emergency rate index (ERI) and days for the

flowering of Desmodium tortuosum seedlings sown at

different depths and submitted to different solar radiation

\begin{tabular}{|c|c|c|c|c|c|c|c|c|}
\hline \multicolumn{9}{|c|}{$(E R I)$} \\
\hline \multirow{2}{*}{$\begin{array}{c}\text { SOWING } \\
\text { DEPTH }(\mathrm{cm})\end{array}$} & \multicolumn{8}{|c|}{ \% OF SOLAR RADIATION } \\
\hline & \multicolumn{2}{|c|}{100} & \multicolumn{2}{|c|}{70} & \multicolumn{2}{|c|}{50} & \multicolumn{2}{|c|}{30} \\
\hline 0.5 & 2.51 & Ba & 2.57 & Aa & 2.49 & $\mathrm{Aa}$ & 2.29 & $\mathrm{Aa}$ \\
\hline 1.0 & 2.10 & Сa & 2.42 & Aa & 2.46 & $\mathrm{Aa}$ & 2.21 & Aa \\
\hline 2.0 & 3.15 & Aa & 2.56 & $A b$ & 2.12 & Ac & 2.03 & Ac \\
\hline 4.0 & 1.81 & Ca & 1.53 & $\mathrm{~B}$ & 1.52 & Ba & 1.55 & Ba \\
\hline 8.0 & 0.18 & Da & 0.03 & a & 0.10 & $\mathrm{Ca}$ & 0.25 & Ca \\
\hline 12.0 & 0.02 & Da & 0.00 & Ca & 0.00 & Ca & 0.00 & Ca \\
\hline $\mathrm{F}_{\mathrm{LIGHT}}(\mathrm{L})$ & \multicolumn{8}{|c|}{$10.358^{* *}$} \\
\hline $\mathrm{F}_{\text {DEPTH }}(\mathrm{D})$ & \multicolumn{8}{|c|}{$744.818^{* *}$} \\
\hline$F(L) \times(D)$ & \multicolumn{8}{|c|}{$13.681^{* *}$} \\
\hline LSD (L) & \multicolumn{8}{|c|}{0.31} \\
\hline LSD (D) & \multicolumn{8}{|c|}{0.34} \\
\hline C. V. (\%) & \multicolumn{8}{|c|}{10.1} \\
\hline
\end{tabular}

\begin{tabular}{|c|c|c|c|c|}
\hline \multicolumn{5}{|c|}{ DAYS FOR FLOWERING } \\
\hline \multirow{2}{*}{$\begin{array}{c}\text { SOWING } \\
\text { DEPTH }(\mathrm{cm})\end{array}$} & \multicolumn{4}{|c|}{ \% OF SOLAR RADIATION } \\
\hline & 100 & 70 & 50 & 30 \\
\hline 0.5 & 118 & 119 & 139 & 139 \\
\hline 1.0 & 118 & 119 & 139 & 139 \\
\hline 2.0 & 118 & 119 & 139 & 139 \\
\hline 4.0 & 118 & 119 & 139 & 139 \\
\hline 8.0 & 118 & 119 & 139 & 139 \\
\hline 12.0 & 118 & -- & -- & -- \\
\hline
\end{tabular}

** Significant at $1 \%$ probability. Means followed by the same uppercase letter in the column do not differ statistically from each other by the Tukey test $(p<0.05)$. 
Plants of this species subjected to extreme light conditions (100 and 30\% solar radiation) had the lowest flowering height when sown at a depth from 0.5 to $8.0 \mathrm{~cm}$. Thus, it is inferred the existence of a possible ecological adaptation of this species to intermediate shading conditions, as $D$. tortuosum plants presented the highest heights under 70 and $50 \%$ solar radiation conditions and sowing depth of up to $8.0 \mathrm{~cm}$ (Table 11).

The numerical evaluation of the height of $D$. tortuosum plants during flowering showed that the plants developed at $50 \%$ solar radiation had the highest mean heights. However, these plants remained for 20 and 21 more days in the field than plants grown at 100 and $70 \%$ solar radiation, respectively (Table 11).

It should be noted that solar radiation is an important environmental component that provides light energy for photosynthesis and provides environmental signals for a series of physiological processes in plants that can differ depending on the plant species (Marchi et al., 2020). The reduction in light intensity and, consequently, temperature culminates in a decrease in the accumulation of degree-days by the plant, which directly influences plant phenology and morphogenesis. In this case, the plants tend to stay longer in vegetative stages and bloom later or unevenly concerning the different levels of shading (Marques et al., 2012). For weeds, this can also occur as an adaptive response of different species to environmental conditions in an attempt to ensure that in the future, there are ideal conditions for the beginning of reproductive stages, ensuring the propagation and survival of future generations.

The different sowing depths also affected the height of $D$. tortuosum plants within each light intensity, with similar plant heights at sowing depths from 0.5 to $12.0 \mathrm{~cm}$ in the treatment with $100 \%$ solar radiation, 0.5 to $8.0 \mathrm{~cm}$ in

\begin{tabular}{|c|c|c|c|c|c|c|c|c|}
\hline \multirow{3}{*}{$\begin{array}{l}\text { SOWING } \\
\text { DEPTH }(\mathrm{cm}) \\
0.5\end{array}$} & \multicolumn{8}{|c|}{ \% OF SOLAR RADIATION } \\
\hline & \multicolumn{2}{|c|}{100} & \multicolumn{2}{|c|}{70} & \multicolumn{2}{|l|}{50} & \multicolumn{2}{|c|}{30} \\
\hline & 37.95 & Ac & 104.00 & Aab & 134.41 & $\mathrm{Aa}$ & 69.08 & Abc \\
\hline 1.0 & 28.33 & $A b$ & 106.67 & Aa & 132.41 & Aa & 61.45 & $A b$ \\
\hline 2.0 & 34.99 & Ac & 109.08 & Aab & 123.91 & $\mathrm{Aa}$ & 75.67 & $A b c$ \\
\hline 4.0 & 48.58 & Ac & 117.25 & Aab & 136.74 & $\mathrm{Aa}$ & 79.08 & $A b c$ \\
\hline 8.0 & 51.00 & $A b$ & 104.25 & $\mathrm{Aa}$ & 89.00 & $\mathrm{Ba}$ & 32.17 & $\mathrm{ABb}$ \\
\hline 12.0 & 21.00 & $\mathrm{Aa}$ & 0.00 & Ba & 0.00 & Ca & 0.00 & Ba \\
\hline $\mathrm{F}_{\mathrm{LIGHT}}(\mathrm{L})$ & \multicolumn{8}{|c|}{$37.588^{* *}$} \\
\hline $\mathrm{F}_{\mathrm{DEPTH}}(\mathrm{D})$ & \multicolumn{8}{|c|}{$31.380^{* *}$} \\
\hline$F(L) \times(D)$ & \multicolumn{8}{|c|}{$3.896^{* *}$} \\
\hline LSD (L) & \multicolumn{8}{|c|}{44.23} \\
\hline LSD (D) & \multicolumn{8}{|c|}{49.23} \\
\hline C. V. (\%) & \multicolumn{8}{|c|}{34.0} \\
\hline
\end{tabular}

**Significant at $1 \%$ probability. Means followed by the same uppercase letter in the column do not differ statistically from each other by the Tukey test $(p<0.05)$ treatments with 70 and $30 \%$ solar radiation, and 0.5 to 4.0 $\mathrm{cm}$ in the treatment with $50 \%$ solar radiation (Table 11 ).

In addition to the plant height, the total and daily dry matter accumulation of $D$. tortuosum plants was also evaluated at flowering and the results showed that both the sowing depth and light intensity factors isolated regarding the interaction between them affected both characteristics (Table 12).

Plants developed at $100 \%$ solar radiation showed similar values of total and daily dry matter accumulation until flowering in all the evaluated sowing depths, as observed in plants developed under $30 \%$ solar radiation. Intermediate conditions of light, that is, 70 and $50 \%$ solar radiation, provided the highest values of dry matter and daily accumulation in plants sown at depths from 0.5 to 8.0 $\mathrm{cm}$ and 0.5 to $4.0 \mathrm{~cm}$, respectively (Table 12).

\section{Table 12 - Total dry matter accumulation at flowering and} daily dry matter accumulation until flowering of Desmodium tortuosum plants sown at different depths and submitted to different solar radiation intensities. TOTAL DRY MATTER ACCUMULATION (g)

\begin{tabular}{|c|c|c|c|c|c|c|c|c|}
\hline \multirow{2}{*}{$\begin{array}{l}\text { SOWING } \\
\text { DEPTH } \\
\text { (cm) }\end{array}$} & \multicolumn{8}{|c|}{ \% OF SOLAR RADIATION } \\
\hline & \multicolumn{2}{|r|}{100} & \multicolumn{2}{|c|}{70} & \multicolumn{2}{|c|}{50} & \multicolumn{2}{|l|}{30} \\
\hline 0.5 & 1.16 & & 4.09 & ABab & 7.19 & Aa & 0.51 & $A b$ \\
\hline 1.0 & 1.05 & & 5.06 & Aa & 7.97 & Aa & 0.76 & $A b$ \\
\hline 2.0 & 1.63 & & 5.02 & Aab & 8.05 & $\mathrm{Aa}$ & 1.23 & Ac \\
\hline 4.0 & 1.42 & & Abc $\quad 5.46$ & Aa & 4.80 & ABab & 0.96 & Ac \\
\hline 8.0 & 3.23 & & Aab $\quad 6.46$ & $\mathrm{Aa}$ & 3.95 & BCab & 0.38 & $A b$ \\
\hline 12.0 & 0.63 & & 0.00 & $\mathrm{Ba}$ & 0.00 & $\mathrm{Ca}$ & 0.00 & Aa \\
\hline$F_{\text {LIGHT }}(\mathrm{L})$ & \multicolumn{8}{|c|}{$28.586^{* *}$} \\
\hline $\mathrm{F}_{\mathrm{DEPTH}}(\mathrm{D})$ & \multicolumn{8}{|c|}{$7.802^{* *}$} \\
\hline$F(L) \times(D)$ & \multicolumn{8}{|c|}{$2.950^{\star *}$} \\
\hline LSD (L) & \multicolumn{8}{|c|}{3.73} \\
\hline LSD (D) & \multicolumn{8}{|c|}{4.15} \\
\hline C. V. (\%) & \multicolumn{8}{|c|}{59.0} \\
\hline \multicolumn{9}{|c|}{ DAILY DRY MATTER ACCUMULATION (g dia-1) } \\
\hline \multirow{2}{*}{$\begin{array}{l}\text { SOWING } \\
\text { DEPTH } \\
(\mathrm{cm})\end{array}$} & \multicolumn{8}{|c|}{ \% OF SOLAR RADIATION } \\
\hline & \multicolumn{2}{|c|}{100} & \multicolumn{2}{|l|}{70} & \multicolumn{2}{|l|}{50} & \multicolumn{2}{|l|}{30} \\
\hline 0.5 & 0.0098 & Abc & 0.0346 & Aab & 0.0517 & Aa & 0.0037 & $A c$ \\
\hline 1.0 & 0.0093 & $A b$ & 0.0429 & Aa & 0.0573 & Aa & 0.0057 & $A b$ \\
\hline 2.0 & 0.0138 & $A b$ & 0.0425 & Aa & 0.0579 & $\mathrm{Aa}$ & 0.0089 & $A b$ \\
\hline 4.0 & 0.0120 & Abc & 0.0462 & $\mathrm{Aa}$ & 0.0345 & Aab & 0.0069 & $A c$ \\
\hline 8.0 & 0.0273 & $A b$ & 0.0547 & Aa & 0.0285 & ABa & 0.0028 & $A b$ \\
\hline 12.0 & 0.0053 & $\mathrm{Aa}$ & 0.0000 & Ba & 0.0000 & Ba & 0.0000 & $\mathrm{Aa}$ \\
\hline $\mathrm{F}_{\mathrm{LIGHT}}(\mathrm{L})$ & \multicolumn{8}{|c|}{$32.374^{\star *}$} \\
\hline $\begin{array}{l}\mathrm{F}_{\mathrm{DEPTH}} \\
\text { (D) }\end{array}$ & \multicolumn{8}{|c|}{$9.129^{* *}$} \\
\hline$F(L) \times(D)$ & \multicolumn{8}{|c|}{$3.306^{* *}$} \\
\hline LSD (L) & \multicolumn{8}{|c|}{0.0268} \\
\hline LSD (D) & \multicolumn{8}{|c|}{0.0299} \\
\hline C. V. (\%) & \multicolumn{8}{|c|}{52.0} \\
\hline
\end{tabular}

**Significant at $1 \%$ probability. Means followed by the same uppercase letter in the column do not differ statistically from each other by the Tukey test $(p<0.05)$ 
Each sowing depth also showed the effect of light intensities on the total and daily dry matter accumulation until the flowering of $D$. tortuosum plants. Sowing depths from 0.5 to $4.0 \mathrm{~cm}$ provided the highest dry matter means in plants grown under 70 and $50 \%$ solar radiation, also providing the plants with the highest height (Table 12).

The highest total dry matter accumulations for the sowing depth of $8.0 \mathrm{~cm}$ were observed in plants grown under 100,70 , and $50 \%$ solar radiation. Moreover, D. tortuosum seeds sown at a depth of $12.0 \mathrm{~cm}$ provided emergence only under the $100 \%$ solar radiation condition, with no differences between light intensities, as the emerged plants grew a little and hardly accumulated dry matter. The highest daily dry matter accumulations were observed in plants developed under 70 and $50 \%$ sunlight at sowing depths from 0.5 to $8.0 \mathrm{~cm}$ even with the flowering of $D$. tortuosum plants occurring in less time under the $100 \%$ solar radiation condition (Table 12).
These data show the great competitive and development potential of $D$. tortuosum plants under shading conditions. According to Procópio et al. (2003), D. tortuosum plants showed the highest leaf emission rate (leaflets) and the longest leaf area duration compared to E. heterophylla plants when developed under shading conditions.

Thus, generally, the results obtained in this work about the emergence and development of E. heterophylla and D. tortuosum sown in different soil depths and light intensities can assist in the effective management of these weeds species through the adoption of methods that reduce or prevent their occurrence.

\section{Author's contributions}

GSFS, RFM, SRM, and DM: Writing. MRRP, SRM and DM: Statistical analysis.

\section{References}

Guimarães LADOP, Dariva MD, Oliveira SBD, Bellon AA, Mendonça GCD. [Germination and seedling vigor of Myrciario glazioviono submitted to shading]. Rodriguésia. 2018;69(4):2237-43. Portuguese. Available from: https://doi.org/10.1590/2175-7860201869448

Klein AL, Felippe GM. [Effect of light in the germination of weed seed]. Pesq Agropec Bras. 1991;26(7):955-66. Portuguese.

Lessa BFT, Ferreira VM, Araújo Neto JC, Souza RC. [Germination of emilia coccinea (Sims) G. DON as a function of light, temperature, storage and sowing depth]. Semina Cienc Agr. 2013;34(6 Suppl.1):3193-204. Portuguese. Available from: https://doi.org/10.5433/1679-0359.2013v34n6Supl1p3193

Machado Neto JGM, Pitelli RA. [The sowing depth on the emergency of wild peanut]. Pesq Agropec Bras. 1988;23(11):1203-8. Portuguese.

Maciel CDG. [Weed control methods]. In: Monquero PA. [Aspects of weed biology and management]. São Carlos: RiMa; 2014. p. 129-44. Portuguese.

Maguire JD. Speed of germination: aid in selection and evaluation for seedling emergence and vigor. Crop Sci. 1962;2(2):176-7. Available from: https://doi.org/10.2135/cropsci1962.0011183Х000200020033x

Marchi SR, Marques RF, Souza RM, Justo CF, Martins CC. Straw interference in the emergence of talquezal seeds from different origins. Planta Daninha. 2020;38:1-8. Available from: https://doi.org/10.1590/S0100-83582020380100059

Marchi SR, Sousa AC, Marques RF, Pinheiro GHR, Souza RM, Martins D. Potential of greenhouse gas production by Guinea grass subjected to weed competition. J Agric Sci. 2019;11(8): 257-72. Available from: https://doi.org/10.5539/jas.v11n8p257

Marques AS, Marchi SR, Pinheiro GHR, Marques RF, Martins CC. Emergence of razor grass on the basis of origin and seed depth in the soil profile. Planta Daninha. 2019;37:1-10. Available from: https://doi.org/10.1590/S0100-83582019370100126
Marques RP, Martins D, Costa SIA, Vitorino HS. [Densities strawand luminosity conditions on seed germination on seed germination of Euhphorbia heterophylla]. Semina Cienc Agr. 2012;33(3):867-72. Portuguese. Available from: https://doi.org/10.5433/1679-0359.2012v33n3p867

Monquero PA, Hijano N, Orzari I, Sabbag RS, Hirata ACS. [Sowing depth, soil texture, $\mathrm{pH}$ and management of straw on germination of Rottboellia exaltoto]. Semina Cienc Agr. 2012;33(1):2799-812. Portuguese. Available from: https://doi.org/10.5433/1679-0359.2012v33Supl1p2799

Monquero PA, Orzari I, Silva PV, Penha AS. Interference of weeds on seedlings of four neotropical tree species. Acta Scientiat Agron. 2015;37(2):219-32. Available from: https://doi.org/10.4025/actasciagron.v37i2.19280

Montanha DA, Alves JMA, Silva MR, Matos WS, Silva DCO, Barreto GF. [Dormancy-breaking and the influence of sowing depth on seed germination in Desmodium tortuosum]. Rev Agro@mbiente. 2018;12(1):34-40. Portuguese. Available from: https://doi.org/10.18227/1982-8470ragro.v12i1.4353

Neves ELD, Funch LS, Viana BF. [Phenological behavior of three species of Jatropha (Euphorbiaceae) in the semi-arid caatinga region of Brazil]. Braz J Bot. 2010;33(1):155-66. Portuguese. Available from: https://doi.org/10.1590/S0100-84042010000100014

Oliveira Jr. RS, Delistoianov F. [Seeding depth and dormancy breaking methods affecting germination and emergence of Desmodium purpureum (Mill.) Fawc. et Rend. (Leguminosae-Papilionoideae)]. Braz J Bot. 1996;19(2):221-5. Portuguese.

Pacheco LP, Pires FR, Monteiro FP, Procópio SO, Assis RLD, Petter FA. [Depth of sowing and initial growth of forage species used for soil coverage]. Cienc Agrotec. 2010;34(5):1211-8. Portuguese. Available from: https://doi.org/10.1590/S1413-70542010000500019

ProcópioSDO,SantosJBD,SilvaAAD,CostaLC. [Leafdevelopmentofsoybean and bean crops and weeds]. Cienc Rural. 2003;33(2):207-11. Portuguese. Available from: https://doi.org/10.1590/S0103-84782003000200005 
Ramesh K, Rao AN, Chauhan BS. Role of crop competition in managing weeds in rice, wheat, and maize in India: a review. Crop Prot. 2017;95:1421. Available from: https://doi.org/10.1016/j.cropro.2016.07.008

Santos FLS, Melo WRF, Coelho PHM, Benett CGS, Dotto MC. [Initial growth of Urochloo species as affected by sowing depth] Rev Agric Neotrop. 2015;2(4):1-6. Portuguese. Available from: https://doi.org/10.32404/rean.v2i4.685

Sérgio C, Lincoln GC, Zacarias XB, Armindo AAJ, Fernanda LR. [Physical conservation srveying in of Lavapes river basin, Botucatu, SP]. Rev Fac Agron. 2005;22(2):167-80. Portuguese.

Silva EM, Pereira JC, Ferreira VM, Souza R. Germination of Stigmaphyllon blanchetii seeds in different temperatures and luminosity. Planta Daninha. 2019;37:1-9. Available from: https://doi.org/10.1590/S0100-83582019370100120
Taiz L, Zeiger E. [Plant physiology]. 5th ed. Porto Alegre: Artmed; 2013. Portuguese.

Vieira BC, Rodrigues BM, Garcia QS. Light exposure time and light quality on seed germination of Vellozio species (Velloziaceae) from brazilian campo rupestre. Flora. 2018;238:94-101. Available from: https://doi.org/10.1016/j.flora.2017.01.012

Zuffo AM, Andrade FR, Silva LMA, Menezes KO, Silva RL, Piauilino AC. [Sowing depth and breaking dormancy at early seed growth of Brachiario dyctioneura (Fig. \& De Not.) Stapf (1919) cv. Llanero]. Rev Ceres. 2014;61(6):948-55. Portuguese. Available from: https://doi.org/10.1590/0034-737X20146106009 